\title{
Engaging plant anatomy and local knowledge on the buriti palm (Mauritia flexuosa L.f.: Arecaceae): the microscopic world meets the golden grass artisan's perspective
}

\author{
Rebeca V. R. Viana ${ }^{1,2}$ (D) Vera L. Scatena ${ }^{3} \cdot$ Mayra T. Eichemberg $^{4} \cdot$ \\ Paulo T. Sano ${ }^{1}$
}

Received: 25 September 2014/Accepted: 30 August 2016/Published online: 4 November 2016

(C) Springer Science+Business Media Dordrecht 2016

\begin{abstract}
Considering that both Western Science and Local Knowledge Systems share a common ground - observations of the natural world - the dialogue between them should not only be possible, but fruitful. Local communities whose livelihoods depend on traditional uses of the local biodiversity not only develop knowledge about nature, making several uses of such knowledge, but, with that process, several inquiries about nature can be raised. Here we present our experience with the engagement of Western Science with golden grass artisan's knowledge about the buriti palm (M. flexuosa). We applied 25 semidirective interviews, combined with field diary and participative observation, in two quilombola communities from Jalapão region (Central-Brazil). One of the inquiries that emerged from the artisan's perspectives was about the differences between male and female buriti palms' fiber. We then engaged both local and scientific perspectives regarding this issue using plant anatomy as a dialogue instrument. Here we describe this experience and resort to Paulo Freire's ideas on dialogue to argue that, to integrate Western Science and Local Knowledge Systems in a collaborative and contextualized perspective, the research should be faced as a mutual learning practice.
\end{abstract}

Keywords Local knowledge systems · Plant anatomy · Buriti palm · Dialogue · Jalapão · Golden grass handicraft

Lead editor: C. Castano Rodriguez.

Rebeca V. R. Viana

rvrviana@gmail.com

1 Instituto de Biociências, Universidade de São Paulo, São Paulo, SP, Brazil

2 Pesquisa e Conservação do Cerrado - PEQUI, Brasília, DF, Brazil

3 Instituto de Biociências, Universidade Estadual Paulista Júlio de Mesquita Filho, Rio Claro, SP, Brazil

4 Centro de Educação Superior do Oeste, Universidade do Estado de Santa Catarina, Chapecó, SC, Brazil 


\section{Resumo executivo}

Uma das premissas para o diálogo entre Ciência Ocidental (CO) e Sistemas de Conhecimento Locais (SCL) é que ambas perspectivas são construídas a partir de observações do mundo natural e geram, além de conhecimentos diversos sobre a natureza e práticas de uso da biodiversidade, questões sobre o mundo natural. As pesquisas relacionadas às interações entre CO e SCL, geralmente, contextualizam os organismos estudados na macro-escala. Os resultados aqui descritos trazem a possibilidade de trabalho em outra escala: a microscópica. Mesmo nessa escala, há possibilidades, também, para uma prática de pesquisa culturalmente sensível. O presente artigo apresenta os resultados de uma pesquisa realizada sobre a palmeira buriti (Mauritia flexuosa, Arecaceae) onde a anatomia de plantas foi utilizada como ferramenta de diálogo. A partir das idéias de Paulo Freire sobre diálogo, apresenta-se o argumento de que para integrar CO e SCL é preciso que o processo de pesquisa de campo seja desenvolvido como uma prática de aprendizado mútuo. Nossa pesquisa foi realizada com a colaboração de duas comunidades quilombolas da região do Jalapão (TO): Mumbuca e Prata, ambas produtoras de artesanato de capim-dourado, tradicionalmente costurado com fibras de buriti. O ponto de partida para os resultados aqui apresentados foi um questionamento feito por duas jovens artesãs: "nós gostaríamos de saber por que o buriti-fêmea produz uma seda [fibra do buriti] melhor que o olho [folhas jovens] do buriti-macho".

O conhecimento local sobre a extração da seda de buriti foi sistematizado por meio de 25 entrevistas semi-diretivas, combinadas com dados de diários de campo e observação participativa. Todas as entrevistas foram acompanhadas por uma jovem de cada comunidade, cuja participação foi crucial na adaptação da linguagem durante as entrevistas e para a contextualização dos dados preliminares. Os dados das entrevistas foram analisados por meio de Análise de Conteúdo. Esses resultados preliminares foram, então, apresentados para artesãos mais velhos de ambas as comunidades e discutidos em sessões de grupo focal. Para a investigação anatômica, foram realizadas coletas colaborativas, onde os artesãos coletaram exemplares de folhas jovens de buriti-fêmea e buriti-macho, identificados de acordo com a perspectiva local e analisados conforme metodologia de anatomia vegetal.

Os resultados estão apresentados em duas etapas: (1) uma sistematização do conhecimento local sobre o buriti, dentro do contexto da extração da seda de buriti; (2) e os resultados da investigação de anatomia vegetal, inspirada na perspectiva local sobre o buriti. $\mathrm{O}$ artigo também apresenta uma breve descrição da atividade de devolutiva realizada ao fim do projeto de pesquisa, quando lâminas de buriti foram apresentadas aos artesão em microscópios, com o objetivo de propiciar uma experiência visual em que os participantes visualizassem o buriti "por dentro", sem a intenção ensinar conceitos de anatomia vegetal. Por fim, ressalta-se que a investigação do conhecimento local sobre a extração da seda do buriti, seguida da investigação de anatomia vegetal e da atividade de devolutiva foi realizada sem a intenção de validar uma perspectiva acima da outra, mas sim promover a valorização da co-existência de uma diversidade de sistemas de conhecimento sobre a natureza.

"We even smile of this story. The female, her silk is very soft. And the male, he's really an old, thick being. The silk is too crisped, the silk isn't good for the women to work with it. His "palha" [leaf] is too crisped, the male buriti. I know it. Just looking at its "talo" [petiole] I know which buriti it is, even though it isn't producing [fruits or flowers] yet." 
A gente até sorri do causo. A fêmea, a seda dela é bem macia. E o macho, ele é um bicho velho grosseiro mesmo. A seda é muito crespa, a seda não é muito boa pra mulher trabalhar com ela. A palha dele muito crespa, do buriti macho. Eu conheço ele. Só olhar pro talo dele eu conheço qual é o buriti, sem ele produzir ainda, né. Sr. Juracir, from Prata Community

The following article presents the results of the engagement of Western Science and Local perspectives on the buriti palm (Mauritia flexuosa L. f.) within the context of plant anatomy. We worked with the collaboration of two of Central Brazil's quilombola communities from the Jalapão region (Tocantins state, Brazil): Mumbuca and Prata. The local communities that live in Jalapão have developed traditional uses of the Brazilian Savanna's biodiversity over time, being the golden grass handicraft one of the most distinguished. The activity, when performed according to local knowledge, is sustainable (Schmidt and Ticktin 2012) and involves the use of two species: Syngonanthus nitens (golden grass) scapes (Schmidt et al. 2007) and a fiber-locally known as buriti-silk-extracted out from Mauritia flexuosa's (buriti palm) newly formed leaves's-locally known as buriti-eye (Sampaio et al. 2008). Both species occur in the Veredas, a swamp landscape marked by buriti palm that are typically used in multiple forms where they occur (Sampaio et al. 2012). In Table 1, the basic information about the golden grass handicraft and the extraction of buriti fibers in Jalapão is systematized.

The starting point of the results herein was an inquiry made by two young artisans from Mumbuca, within Rebeca Viana's master research project that aimed to investigate the associations between scientific and local perspectives on the golden grass and the buriti palm Jalapão (Viana 2013):

We would like to know why the 'female' buriti provides a better silk than the 'male' buriti-eye?

Table 1 Basic information to understand the use of buriti fibers by golden grass handicraft artisans from the Jalapão region

\begin{tabular}{|c|c|}
\hline $\begin{array}{l}\text { Golden grass handicraft (in portuguese: } \\
\text { artesanato de capim-dourado) }\end{array}$ & $\begin{array}{l}\text { Is a bright and gold handicraft traditional from Jalapão region. } \\
\text { The most traditional pieces are baskets and hats, but recently } \\
\text { artisans have been also producing bracelets, belts, earrings, } \\
\text { purses etc. Nowadays, the handicraft is an important source } \\
\text { of income for local artisans (Schmidt et al. 2007). }\end{array}$ \\
\hline
\end{tabular}

Jalapão

Mumbuca and Prata

Buriti palm

Buriti-eye (in portuguese: olho-do-buriti)

Buriti silk (in portuguese: seda-do-buriti)
Is a region in Central-Brazil that holds, in nearly $53.000 \mathrm{~km}^{2}$, one of the country's largest areas of Brazilian Savanna remainings (Schmidt et al. 2011).

Are two quilombola communities from Jalapão. Golden grass artisans from both communities participated in our research.

Mauritia flexuosa (Arecaceae); is a dioecious - presents male and female organs separated in distinct individuals - palm used extensively by local communities where it occurs (Sampaio et al. 2012).

Is the newly formed leaf from the buriti palm. In Jalapão, the artisans only extract the buriti-eye from young buriti palms, still in its vegetative stage (Sampaio et al. 2008)

Is the fiber extracted from buriti young leaves. This fiber is traditionally used to sew the golden grass handicraft (Sampaio et al. 2008) 
Such a question intrigued us since, in the Jalapão region, the buriti silk is only extracted from young buriti palms. Thus, how could the artisans make such identification, between 'male' and 'female' buriti, without the presence of the palm's reproductive features? Also, in the artisan's perspective how was the female buriti-silk different from the male buritisilk? Why was this considered an important matter for the golden grass handicraft artisans? Thus, the artisan's preferences regarding the buriti-silk's extraction inspired us to engage in a plant anatomy research project to investigate the young buriti leaves within the context of their perspective.

Here we present (1) the local knowledge about the buriti palm framed in the context of the buriti silk extraction, as well as (2) the results of the plant anatomy investigation inspired by this local perspective. In our view, the interaction between local and scientific perspectives as presented here were only possible and fruitful due to the establishment of a dialogic data collection practice that involved a mutual learning process between us and the research participants.

\section{Western science and local knowledge systems interaction as a dialogic practice}

Our research was, initially, inspired by Henry Huntington's paper on the possible gains of approximating local and scientific perspectives for both local communities and scientists, where the author incites natural scientists to "join the conversation" on this matter (2011, p. 183). Even though Local Knowledge Systems (LKS) and Western Science (WS) constitute different paths to knowledge, they are rooted in the same reality (Mazzolcchi 2006). Hence, accessing LKS has been considered an important innovation resource for scientists to better understand themes such as health, nutrition, education, culture and conservation, as well as to contribute to the enhancement of local communities' empowerment mechanisms (Vanderbroek et al. 2011).

Both, WS and LKS equally seek to make sense of the world (Aikenhead and Michell 2011), standing for an understanding of its dynamics (Cunha 2009). Also, WS and LKS share fundamental commonalities and intellectual processes such as observing, questioning, interpreting, inferring, classifying etc.; differences, however, appear on the way each cultural group enacts such processes (Aikenhead and Michell 2011). In this context, we share Charbel El-Hani and Pedro Bandeira's argument: there're several ways to obtain knowledge on nature and LKS should be legitimated and valuable in terms of its own epistemic criteria, built on specific cultural backgrounds. Furthermore, according to the authors, science should be considered as a specific and well defined way of knowing that involves the development of discourses on nature that have been socio-historically built in modern societies, since the seventeenth century (2008). In our view, this perspective is important in the context of WS and LKS integration as it reinforces the "recognition of TEK [or LKS] as a valid way of knowing and understanding the world without forcing it to conform to the norms and values of Western science" (Lowan 2012, p. 74).

The establishment of collaborative and cultural sensitive research and science education perspectives has been advocated by authors such as Henry Huntigton, Manuela C. Cunha, Glen Aikenhead and Herman Michell, since it could contribute to solve local problems, as well as to achieve a much higher understanding of particular natural phenomenon (2011; 2012; 2011). Still, research perspectives grounded on the integration between LKS and WS or land management have recently been growing in the scientific community and the science education field (Mack et al. 2012). 
Interactions between scientific and local knowledge systems have also been explicitly recommended in official documents such as the "Convention on Biological Diversity" (United Nations 1992a), the "United Nations Conference on Environment and Development-Agenda 21" (United Nations 1992b) and the "Declaration on Science and the Use of Scientific Knowledge" (UNESCO 2000). Likewise, more recently, international scientific platforms such as "Future Earth 2025 Vision" (Future Earth 2014) and "Intergovernmental Platform on Biodiversity and Ecosystem Service" (Diaz et al. 2015) have encouraged scientists engaged in sustainability to co-design and co-produce solution-orientated knowledge with diverse social actors, arguing that WS and LKS should work in complementary and mutually enriching ways.

This scenario, however, represents a great challenge considering that, to properly address it, scientists must learn how to share their research agendas and practices with nonacademic actors. If, on one hand, it's important not to compromise the basic epistemic criteria of WS, on the other hand, scientist must be aware not to "create the conditions whereby an astonishing cultural heritage is transformed into a monolithic structure" (Mazzocchi 2006, p. 465).

Moreover, as stated by Fulvio Mazzocchi, it requires scientists to be opened to participate in the experience of others and accept the invitation of diverse paths of knowledge:

We need to open ourselves to participating in the experience of others, and yet we should also be aware that this opening can only start from where we already arefrom our point of view or the tradition to which we belong. [...] Nevertheless, from our delimited horizon we can still accept the invitation of other paths to knowledge and might as well learn from them. (2006, p. 465)

In our view, Paulo Freire's ideas on dialogue could bring to light this still hazy pathway, if the interaction between scientists and LKS was understood as a mutual learning process. According to Freire, a dialogue should not involve the simple transfer of knowledge between the participants but should, instead, be an act of horizontal co-creation, based on trust (1974/2011).

Finally, Freire invites us to reflect upon the following reflexive questionings about the dialogic practice, that could guide scientists or science educators involved in cultural sensitive practices:

How can I dialogue, if I consider myself as a participant of a ghetto of pure man, owners of the truth and knowledge, for whom all the outsiders are "these people", or are "inferior natives"?

How can I dialogue, if my premisse is that the world's 'pronunciation' is the task of selected man and that the presence of the masses in the history is a sign of its deterioration that I should avoid?

How can I dialogue, if I close myself for the contributions of others, never recognized by me, and if I even feel offended by it? (1974/Freire 2011, p. 111-112, our translation)

\section{Working in collaboration with Jalapão's local communities}

\section{The ethnobotanical data collection}

The field research was conducted by the first author, Rebeca Viana, through participative observation (Alexiades 1996) and semi-directive interviews (Huntington 1998). The data 
collection process involved eight field trips to Jalapão, with an average duration of 10 days each. Since the first field trip, a field diary (Bogdan and Biklen 2006) was developed to register descriptive information regarding the local scenarios, actors and particular events as well as personal reflexions on the research process.

\section{Participative observation}

The participative observation in Mumbuca and Prata communities was practiced through all the field work and involved the researcher's participation in the communities' daily activities in short periods of time (between 3 and 5 days in each community, per field trip) to better understand the local familiar, historical and cultural contexts. Also, one important purpose of the participant observation was the mutual familiarization between the researcher and the artisans and to built a trusting environment for the research process.

\section{Semi-directive interviews}

In each community, the local leaders were consulted in order to suggest one person to assist with the interviews. The assistants, who in both communities were young women, ages 18-20 years old, were contextualized about the research goals and then, together with the local leaders, suggested members of the communities that should be part of the semidirective interviews. Moreover, the assistant's presence was fundamental to better adapt the interviews within the local contexts (Alexiades 1996). In both communities, the interviewed artisans were women-between 23 and 72 years old-who participated actively on the golden grass handicraft local scene. However, since the interview sessions took place inside the artisan's houses, in most cases, it involved the participation of more than one member of the family simultaneously (husband and children). In total, twenty five (25) semi-directive interviews were conducted and recorded in audio. Before each interview session, the Free Informed Consent Form was read and the interview only started if the participant agreed to its content that included the research aims, as well as the voluntary and anonymous aspects of their participation. The semi-directive interviews were structured by the following topics:

(1) How would you describe the buriti palm and the golden grass for someone that has never been to Jalapão?

(2) Do you have any inquiry about the buriti palm and the golden grass that you'd like to share with a scientist researcher?

(3) When I made this same question in a previous interview, I was told that the person interviewed "would like to know why the female's buriti provides a better silk than the male's buriti-eye?". What is your opinion on this matter?

The main purpose of the first topic (1) was to start a conversation about the plant. The transcripts from the semi-directive interviews and the field diary were interpreted through content analysis (Bardin 2004), within a qualitative perspective, in which the description of textual data is made in order to bring a contextual meaning to the raw data (Elo and Kingas 2008; Hsieh and Shannon 2005). Our interpretations were, subsequently, shared with elders and key-actors on the golden grass handicraft local scene (also suggested by local leaders) from both communities through two sessions of focus group, a crucial step for the reliability of our findings. In this article, we focus on the responses for the third topic (3) above, which inspired the plant anatomy project. The results of topics (1) and (2) are discussed in Viana et al. (2014). 


\section{Plant anatomy data collection}

The botanical collection for the plant anatomy investigation was made through collaborative fieldwork (Huntington 2011; Huntington 2000). Key-informants from both communities identified male and female buriti individuals (Mauritia flexuosa L.f. - Arecaceae) (HRCB 54881; 56325, 56326) and extracted its young leaves that were fixed and treated according to plant anatomy methods (Johansen 1940). Petioles and leaf segments were sectioned, stained with basic fuchsin and astra blue (Roeser 1972), and then mounted on semipermanent slides. Whereas, other samples were dehydrated in n-butyl alcohol followed by infiltration in historesin (Leica Embedding Kit Historesin). Cross and longitudinal sections were stained with periodic acid, Schiff reagent (PAS) and toluidine blue (Feder and O'Brien 1968) and mounted on permanent slides. With that, we intended to investigate if there were any anatomical differences between the buriti-silk extracted from locally identified male and female individuals as well as to associate the local differentiation, between both buriti-silk types with the microscopic perspective.

\section{Local perspectives on the buriti palm in Jalapão}

The buriti-silk extraction involves the identification of the proper buriti-eye. For that, the local artisans distinguish the buriti palm as female or male, still in its vegetative form, being the female buriti-silk preferred to sew the golden grass handicraft. The excerpt extracted from one of the interviews illustrates this perspective:

In reality, there's a buriti palm that doesn't produce the 'fruit-bunch'. It only produces flowers. And there's the buriti that produces the fruits. Those [buriti palms] that produce the fruit, they produce a softer silk. It's [buriti-silk] is also stronger and has more resistance. The one that we call male, its silk is not good. (Int. 11)

Furthermore, the participant artisans described the female buriti-silk as being smoother, whitish and more resistant whereas the male buriti-silk would be brittler, shorter, fragile and stilly red:

The male's buriti-eye is different than the female's [...] the male's silk is worst than the female's. The female silk 'comes' smooth and soft. And the male's silk 'comes' rough and short. (Int. 20)

[...] the silk is yellow and weak. And he [the male buriti] is not good for the silk. It's not strong, the silk [...] The difference [between male and female buriti] is only in the buriti's eye, the female's silk is better and the other is worst. (Int. 7)

When asked about the male or female buriti palm identification, through vegetative morphological features, the artisans provided diverse local perspectives. One form to make such identification is to observe the buriti-eye apex, as well as some of the buriti palm open leaves aspects. The female buriti leaves are recognized for its wider open leaf limb and long greenish petiole; on the other hand, male buriti leaves were described as having narrower limbs and shorter grayish petiole.

When the leaf is straight we know that's a male. We don't cut it. When the leaf is wider, open, that's a female. (Int. 17) 
You can look, the buriti with the 'talo' [petiole] really lengthy, that one is the female buriti. And the buriti that you see smaller, with shorter leaves and a shorter 'talo', that one is a male. (Int. 22)

And the male's 'talo' is grayish and the female's is greener (Int. 23)

Alternatively, the artisans can also choose the proper buriti-eye by a machete stroke that is made to the buriti's petiole causing the removal of the epidermis along the peripheric cortex (talinha). If detached continuously, it will be identified as a female buriti, thus buriti-eye will be extracted from the palm; in contrast, if discontinued, it will identified as a male buriti:

We take a machete and extract the 'talinha'. [...] If the 'talinha' don't break, we know it's a female. (Int. 24)

\section{Local knowledge on the buriti palm through plant anatomy's perspective}

According to the plant anatomy analysis, the individuals locally identified as female (1) have a broad mesophyll with round and larger vascular bundles (Fig. 1a, b); the petiole presents round and smaller vascular bundles, but in greater frequency (Fig. 2a, c), with a thick-walled cells constituting a discontinuous subepidermic layer (Fig. 2e). On the other hand, the individuals locally identified as male (2), present narrow mesophyll, with smaller and elongated vascular bundles (Fig. 1c, d); petiole with larger and elongated vascular bundles in lesser frequency (Fig. 2b, d), with a thick-walled cells constituting a continuous subepidermic layer (Fig. 2f). This part of the plant anatomy results, therefore, suggests morphological and anatomical differences between the individuals locally identified as male and female. In this case, the scientific and local knowledge converged.
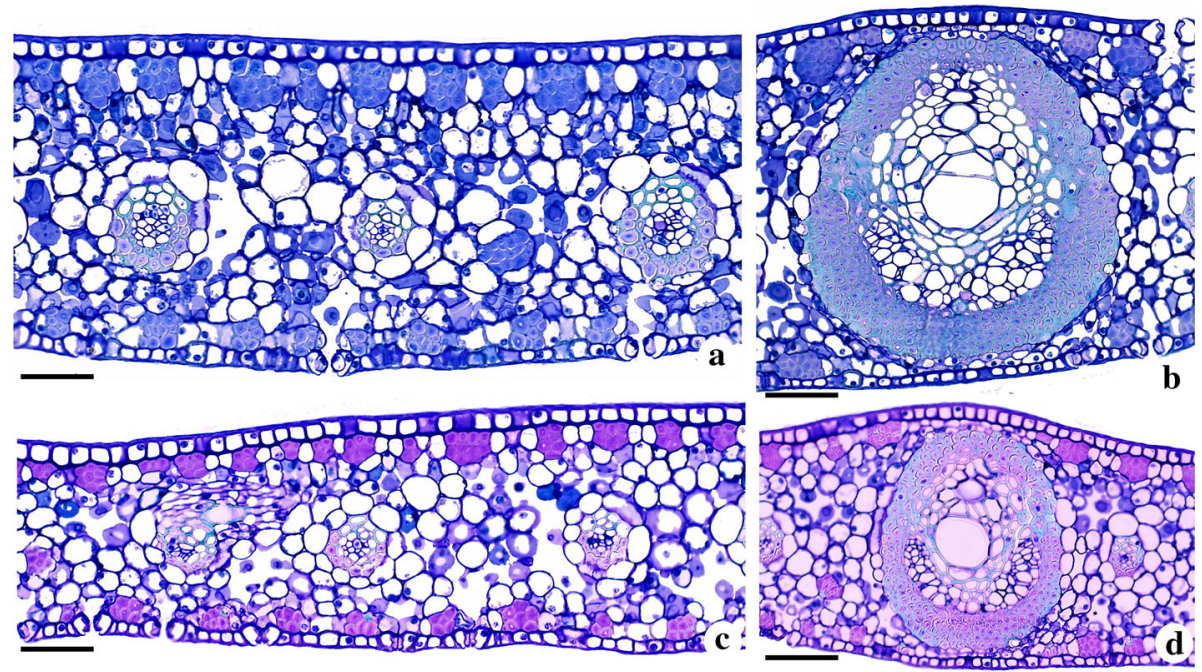

Fig. 1 Cross-section of Mauritia flexuosa young leaf thread. a, b Female individual. a Epidermis and mesophyll. b Detail of vascular bundle. c, d Male individual. c Epidermis and mesophyll. d Detail of vascular bundle. Bars $=70 \mu \mathrm{m}(\mathbf{b}, \mathbf{d}) ; 55 \mu \mathrm{m}(\mathbf{a}, \mathbf{c})$. (Photos: M. Eichemberg) 

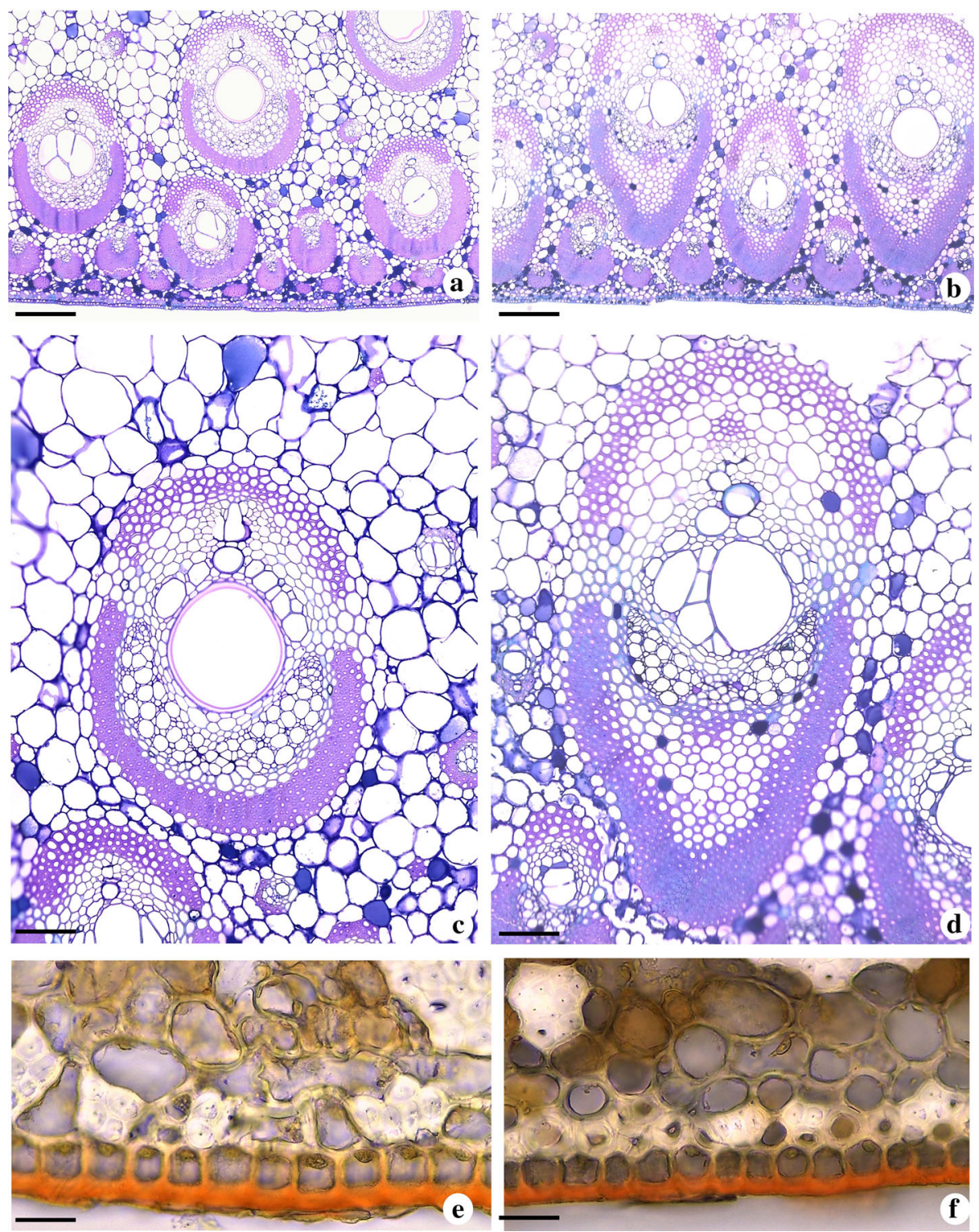

Fig. 2 Cross-section of Mauritia flexuosa young leaf petiole. a, b. Epidermis and peripheral cortex of female (a) and male (b) individuals. c, $\mathbf{d}$. Details of vascular bundles, female (c) and male (d) individual. ef. Details of epidermis and subepidermic layers of female (e) and male (f) individual. Bars $=260 \mu \mathrm{m}(\mathbf{a}, \mathbf{b})$; $60 \mu \mathrm{m}$ (c, d); $25 \mu \mathrm{m}(\mathbf{e}, \mathbf{f})$. (Photos: M. Eichemberg)

The buriti-silk (Fig. 3a) is composed by epidermis and underlying layers, with subepidermic bundles of fiber alternated with parenchymatous cells (Fig. 3b, c). The anatomical structure is similar in both female (Fig. 3d) and male individuals (Fig. 3e). In the abaxial leaf surface of male and female individuals occur stegmata which are cells containing silica bodies. Hence, according to the anatomical analysis there is no difference 

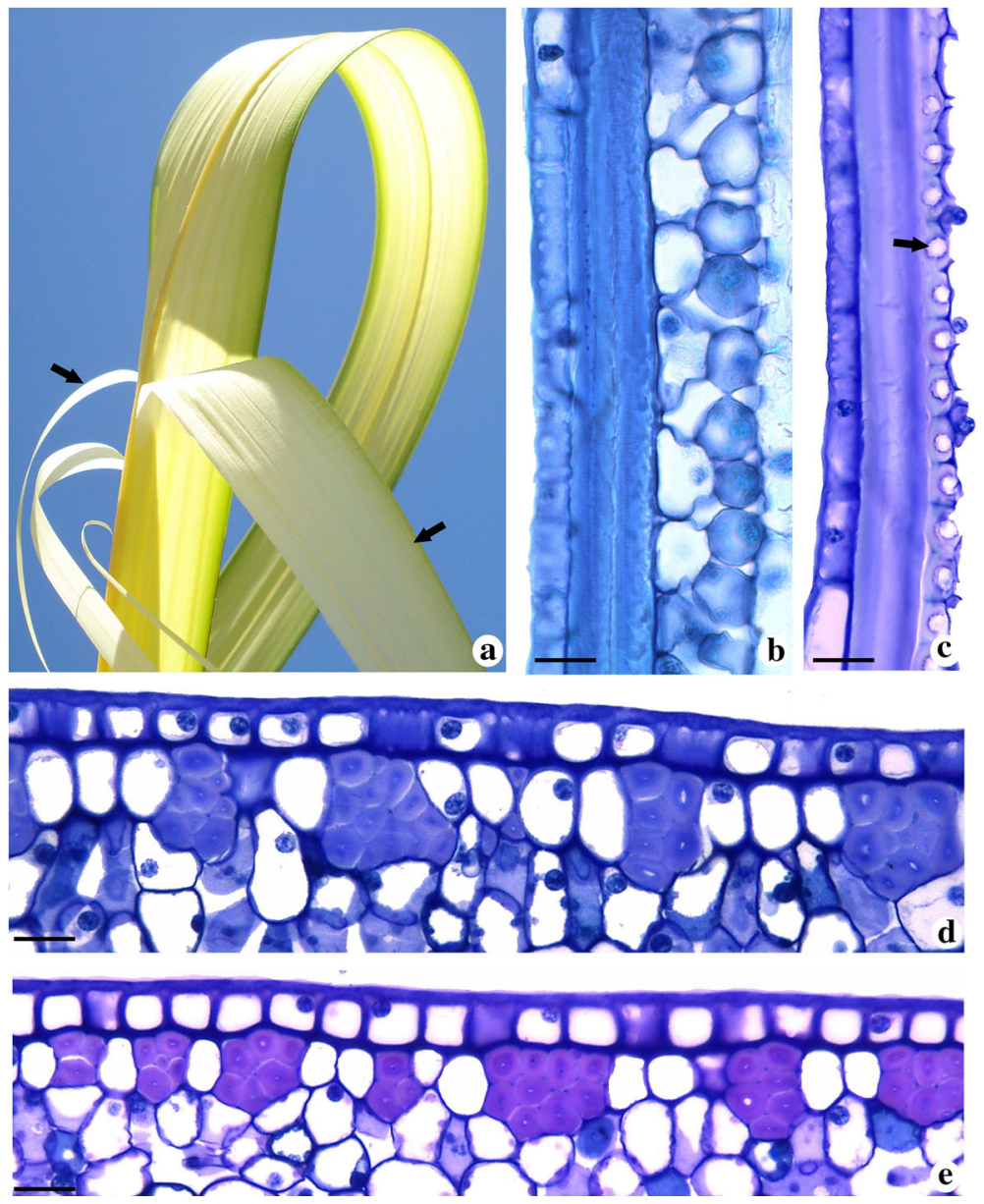

Fig. 3 Morphology and anatomy of Mauritia flexuosa young leaf thread. a. Extraction of silk from female individual. b, c. Longitudinal sections of epidermis and adjacent layers. Details of adaxial (b) and abaxial (c) surface of female individual. d, e. Cross-sections of adaxial surface of female (d) and male (e) individuals. Bars $=30 \mu \mathrm{m}(\mathbf{b}) ; 20 \mu \mathrm{m}$ (c, d, e). (Photos: V. Scatena (3a) and M. Eichemberg (3b-d))

in both types of buriti-silk regarding its flexibility or strength of either male or female buriti palms.

Finally, this capacity to differentiate the female buriti from the male buriti is more common within the communities' elders. Most of the younger artisans consulted affirmed that, although they are able to explain the local identification techniques, they cannot necessarily make such distinction in the field. In addition, it's important to highlight that our research team were not able to make such differentiation when in the field. In this sense, it would be interesting to comprehend, in a future research project, the artisans preferences for the female buriti-silk in a deeper cultural or anthropological perspective, to investigate the symbolism behind the artisan's preferences for the female buriti silk to sew the golden grass handicraft. 


\section{Plant anatomy as an instrument for dialogue: a possible route?}

At the end of the research project, considering that the artisans shared their perspectives with us, in return we brought them buriti palm young leaf and golden grass scape slades on the microscope, so they could observe the plants from "our perspective". These slades were prepared in the presence of the participants. Our main objective was to promote a visual experience, with no intention of transferring our knowledge about plant anatomy to the participants. As described in Rebeca Viana et al. the participants were thrilled to "meet the buriti from the inside" and it was established a "dialogic confluence" with "moments of contemplation of this new perspective of the buriti palm and the golden grass, through the microscope lenses". When we designed this activity we aimed a dialogic process since we considered that it would "materialize our research's conceptual proposal: the search for dialogue possibilities between local and scientific knowledge within the context of the golden grass handicraft artisans" (2014, p. 65). Furthermore, the dialogic proposal of our research was only fulfilled due this final activity. We consider that this type of data sharing, when made without the intent of transferring knowledge but within the perspective of a meeting between cultures (Aikenhead and Michell 2011) is essential in projects that search for a synergistic dialogue between local communities and researchers and promotes the valorization of multiple perspectives on nature.

\section{Final reflection}

The attempts for scientific and local knowledge approximation, most of the times, involves the local communities perceptions and experiences regarding the physical and biological environment characteristics. The studied organisms are usually contextualized in a largescale: habitat, population, community, and biome. Nevertheless, the results described in this article provide a possibility in another scale: the microscopic perspective. Even in this scale, there're possible routes for cultural sensitive scientific and local perspectives engagement. Also, it's important to highlight that this LKS and WS association exercisethe investigation of local knowledge, followed by the plant anatomy project and the devolution activity - was made without the intention of validating one perspective over the other, but to promote the valorization of diverse knowledge systems co-existence. Moreover, considering that the local perspective is part of a wider cultural context with its own epistemic criteria (El-Hani and Bandeira 2008), once again we state that the integration of WS and LKS here described could be understood as a meeting between different cultures (Aikenhead and Michell 2011).

The collaborative aspect of the field work methodologies made it possible for us to "join the conversation" on the interaction between WS and LKS as proposed by Huntington (2011) and conduct a plant anatomy investigation that would not exist otherwise. In our experience, it represented a significant gain on the perspective of possible routes on how to produce knowledge. The application of other participative research perspectives, however, such as community-based participatory research, would certainly improve local communities' empowerment mechanism as well as make a way for co-production of knowledge between WS and LKS.

Overall, a great challenge for WS and LKS engagement that we aimed to address with this article is how to share the world's pronunciation and to be opened for the contribution of others and still not neglect the context, protocols and epistemic criteria of Western 
science. Looking back to Freire's (1974/2011) reflexive inquiries we conclude that, although the pathway is still hazy and that approaches and methodologies are still being developed, one starting point is to consider the field research as a dialogic learning process.

Acknowledgments The authors thank FAPESP (Fundação de Amparo à Pesquisa do Estado de São Paulo; Grant 2010/14534-9) and CNPq (Conselho Nacional de Desenvolvimento Científico e Tecnológico; Grants 307100/2009-0 and 301692/2001-6); Idea Wild and Neotropical Grasslands Conservancy for financial support; NATURATINS (Instituto Natureza do Tocantins) and PEQUI (Pesquisa e Conservação do Cerrado) for the logistic support. We would also like to thank the CSSE revisor careful revision, that certainly enhanced this article quality. We are deeply grateful to people from Jalapão, especially those from Mumbuca and Prata.

Endnote The plant anatomy project was performed in the Plant Anatomy Lab. from São Paulo State University (Unesp-Rio Claro), with Prof. Dr. V. Scatena's supervision.

\section{References}

Aikenhead, G., \& Michell, H. (2011). Bridging cultures: Scientific and indigenous ways of knowing nature. Ontario: Pearson Canada Inc.

Alexiades, M. N. (1996). Collecting ethnobotanical data: An introduction to basic concepts and techniques. In M. N. Alexiades (Ed.), Selected guidelines for ethnobotanical research: A field manual (pp. 53-97). New York: The New York Botanical Garden.

Bardin, L. (2004). Análise de Conteúdo (3rd ed., p. 70). Lisboa: Edições p.

Bogdan, R., \& Biklen, S. (2006). Investigação qualitativa em educação: uma introdução às teorias e aos métodos. Porto: Porto Editora.

Cunha, M. C. (2009). Relações e dissenções entre saberes tradicionais e saber científico. In M. C. Cunha (Coord.), Cultura com Aspas (pp. 301-310). São Paulo: Cosac-Naify.

Cunha, M. C. (2012). Questões suscitadas pelo conhecimento tradicional. Revista de Antropologia, 55(1), 439-464.

Diaz, S., Demissew, S., Carabias, J., Joly, C., Lonsdale, M., Ash, N., et al. (2015). The IPBES conceptual framework: Connecting nature and people. Current Opinion in Environmental Sustainability, 14, 1-16. doi:10.1016/j.cosust.2014.11.002.

El-Hani, C. N., \& Bandeira, F. P. S. F. (2008). Valuing indigenous knowledge: to call it "science" will not help. Cultural Studies of Science Education, 3, 751-779. doi:10.1007/s11422-008-9129-6.

Elo, S., \& Kyngas, H. (2008). The qualitative content analysis process. Journal of Advanced Nursing, 62(1), 107-115. doi:10.1111/j.1365-2648.2007.04569.x.

Feder, N., \& O'Brien, T. P. (1968). Plant microtechnique: Some principles and new methods. American Journal of Botany, 55, 123-142.

Freire, P. (2011). A dialogicidade: essência da educação como prática da liberdade. In P. Freire (Ed.), Pedagogia do oprimido (50th ed., pp. 107-166). Rio de Janeiro: Paz e Terra.

Future Earth. (2014). Future Earth 2025 vision. Paris: Future Earth. Retrieved from: http://www.futureearth. org/sites/default/files/files/Future-Earth_10-year-vision_web.pdf.

Hsieh, H., \& Shannon, S. E. (2005). Three approaches to qualitative content analysis. Qualitative Heath Research, 15(9), 1277-1288. doi:10.1177/1049732305276687.

Huntington, H. P. (1998). Observations on the utility of the semi-directive interview for documenting traditional ecological knowlegde. Artic, 51(3), 237-242.

Huntington, H. P. (2000). Using traditional ecological knowledge in science: Methods and applications. Ecological Applications, 10(5), 1270-1274. doi:10.2307/2641282.

Huntington, H. P. (2011). Artic science: The local perspective. Nature, 478, 182-183.

Johansen, D. (1940). Plant microtechnique. New York: McGraw-Hill Book Co., Inc.

Lowan, G. (2012). Expanding the conversation: Further explorations into indigenous environmental science education theory, research, and practice. Cultural Studies of Science Education, 7, 71-81. doi:10.1007/ s11422-012-9379-1.

Mack, E., Augare, H., Cloud-Jones, L. D., Davíd, D., Gaddie, H. Q., Honey, R. E., et al. (2012). Effective practices for creating transformative informal science education programs grounded in native ways of knowing. Cultural Studies of Science Education, 7, 49-70. doi:10.1007/s11422-011-9374-y. 
Mazzolcchi, F. (2006). Western science and traditional knowledge. European Molecular Biology Organization, 7(5), 463-466.

Roeser, K. R. (1972). Die nadel der schwarzkiefer massen produkt und keinstwerk der natur. Mikrokosmos, 61, 33-36.

Sampaio, M. B., Schmidt, I. B., \& Figueiredo, I. B. (2008). Harvesting effects and population ecology of the buriti palm (Mauritia flexuosa L. f., Arecaceae) in the Jalapão region, Central Brazil. Economic Botany, 62(2), 171-181. doi:10.1007/s12231-008-9017-8.

Sampaio, M. B., Ticktin, T., Seixas, C. S., \& Santos, F. A. M. (2012). Effects of socioeconomics conditions on multiple uses for swamp forests in central Brazil. Human Ecology, 40, 821-831. doi:10.1007/ s10745-012-9519-y.

Schmidt, I. B., Figueiredo, I. B., \& Scariot, A. (2007). Ethnobotany and effects of harvesting on the population ecology of Syngonanthus nitens (Bong.) Ruhland (Eriocaulaceae), a NTFP from Jalapão region, Central Brazil. Economic Botany, 6(1), 73-85. doi:10.1663/0013-0001(2007)61[73: EAEOHO]2.0.CO;2.

Schmidt, I. B., Sampaio, M. B., Figueiredo, I. B., \& Ticktin, T. (2011). Fogo e artesanato de capim-dourado no Jalapão: usos tradicionais e consequências ecológicas. Biodiversidade Brasileira, 2, 67-85.

Schmidt, I., \& Ticktin, T. (2012). When lessons from population models and local ecological knowledge coincide: Effects of flower stalk harvesting in the Brazilian savanna. Biological Conservation, 152, 187-195. doi:10.1016/j.biocon.2012.03.018.

UNESCO. (2000). Declaration on science and the use of scientific knowledge. In World Conference on Science. Science for the Twenty-first Century a New Commitment (pp. 462-467). London: UNESCO. Retrieved from: http://www.unesco.org/science/wcs/eng/declaration_e.htm.

United Nations. (Rio de Janeiro, 1992). Convention on Biological Conservation. United Nations. Retrieved from: http://www.cbd.int/doc/legal/cbd-en.pdf.

United Nations. (Rio de Janeiro, 3 to 14 June, 1992). United Nations Conference on Environmental \& Development - Agenda 21. Retrieved from: https://sustainabledevelopment.un.org/content/documents/ Agenda21.pdf.

Vanderbroek, I., Reyes-Garcia, V., Albuquerque, U. P., Bussmann, R., \& Pieroni, A. (2011). Local knowledge: Who cares? Journal of Ethnobiology and Ethnomedicine, 7(35), 1-12. doi:10.1186/17464269-7-35.

Viana, R. V. R. (2013). Diálogos possíveis entre saberes científicos e locais associados ao capim-dourado e ao buriti na região do Jalapão, TO. Master dissertation presented at the Botany Post graduation Program, Instituto de Biociências, Universidade de São Paulo.

Viana, R. V. R., Sano, P. T., \& Scatena, V. L. (2014). Pesquisa de campo como possibilidade de concretizar oportunidades de diálogo: experiências em duas comunidades artesãs do Japalão: TO. Revista de Desenvolvimento Social, 13, 57-67.

Rebeca V. R. Viana is a Ph.D student in the Department of Botany at USP (São Paulo, SP) and a collaborative researcher in the NGO Pesquisa e Conservação do Cerrado - PEQUI (Brasília, DF). She has been involved in ethnobiology and environmental education projects within traditional communities from the Jalapão region (Central Brazil) since 2010, focusing on engaging local and scientific perspectives on nature within a participative perspective.

Vera L. Scatena is currently a Professor at UNESP, where she develops research with emphasis on Plant Morphology and Anatomy, acting on the following subjects: anatomy applied to Taxonomy; to Ecology; Embryology and seed development, Monocotyledons, Commelinideas, Poales.

Mayra T. Eichemberg is a Professor in the Department of Animal Science, Center for Higher Education of the West, the University of the State of Santa Catarina - UDESC.

Paulo T. Sano is a Professor in the Department of Botany, USP where he directs two research lines: Systematic Phanerogamae, with an emphasis on diversity and evolution of monocots; and Science Education, in particular, Botany and Environmental Education. 